\title{
Assessing the relative efficiency of commercial banks in the Republic of North Macedonia: DEA window analysis
}

\author{
Violeta Cvetkoska ${ }^{1}$ and Katerina Fotova Čiković ${ }^{2, *}$ \\ ${ }^{1}$ Faculty of Economics, Skopje, Ss. Cyril and Methodius University in Skopje \\ Blvd. Goce Delchev 9V, 1000 Skopje, Republic of Macedonia \\ E-mail: 〈vcvetkoska@eccf.ukim.edu.mk〉 \\ 2 Independent Researcher \\ Koprivnička ulica 52G, Starigrad, 48000 Koprivnica, Republic of Croatia \\ E-mail: 〈katerina.fotova@gmail.com〉
}

\begin{abstract}
The aim of this paper is to assess the relative efficiency of commercial banks in one developing country, i.e. the Republic of North Macedonia by using the data envelopment analysis (DEA) technique-window analysis. The selection of inputs and outputs plays a key role when applying DEA for assessing the efficiency of decision-making units (DMUs). In the conducted research two inputs and two outputs have been selected. The sample consists of 14 commercial banks and the period that is being observed is an eleven year span from 2007 to 2017. According to the average efficiency score for the whole observed period, the most efficient bank belongs to the group of large banks, which simultaneously shows the highest efficiency. The banking sector in the Republic of North Macedonia, as a whole, showed the highest efficiency in 2007, and the lowest efficiency in 2011.
\end{abstract}

Keywords: commercial banks, DEA, relative efficiency, window analysis

Received: July 03, 2020; accepted: October 05, 2020; available online: December 18, 2020

DOI: $10.17535 /$ crorr.2020.0017

\section{Introduction}

The financial system in the Republic of North Macedonia is relatively simple, and financial markets are still underdeveloped. It is considered to be a bank-based financial system, where banks play a crucial role in financing the economic activities and maintaining the financial stability of the system, as well as the stability of the other institutional segments. According to Khan and Khattak [15], the banking sector is considered to be the nerve system of a country's economy. If the nerve system fails to function, the whole body becomes useless. Similarly, failure of the banking system will lead to a catastrophe for the entire economic system. Therefore, for the stability and growth of the economy, the banking sector has to function at its optimum level. This can be achieved only if the banking sector is able to allocate the resources efficiently or with minimum waste.

With the break-up of the Socialist Federal Republic of Yugoslavia (SFRY) and the Soviet Union (USSR) in the late 1980s and early 1990s, Central and Eastern European countries have abandoned the system of "planned economy" and have begun to rapidly build economic systems based on market principles and rules, compatible and comparable to those of the developed countries. At the very beginning of this transition process, these countries (including the Republic of North Macedonia) had been given a rather difficult task of successfully fulfilling

${ }^{*}$ Corresponding author. 
the transformation of its financial system, because it was considered that the construction of financial systems based on market principles will contribute to the overall development of these countries and that it will stimulate their economic growth. Despite the large number of national differences and specifics, these countries have inherited the same infrastructural problems, so from here, the tasks and content of the implemented reforms were equal [24].

From the moment monetary independence was established, North Macedonia's banking system was relatively underdeveloped and poor. At the end of 1992, there were only 6 banks in the country, however, as a result of a more liberal approach to the establishment of new banks, in just one year, the number of banks has grown to 20. The consolidation of the banking sector began in 2001 as a result of increased competition in the banking market due to the inflow of foreign capital, as well as reforms in payment systems, which allowed operations to begin taking place through commercial banks.

Banks in the Republic of North Macedonia have been implementing a traditional business model in their operations, i.e. they collect deposits from the domestic and private sector and make placements (as loans) in the domestic households and companies. Other than that, this traditional business model can be identified by the structure of the total revenue of the banks. Namely, around two thirds of the total revenue of the banking sector has come from the net interest revenue [10]. The structure of the total banking revenue in most of the observed period (2007-2017) corresponds with the traditional business model in banks' operations. Thus, net interest revenue, with a share of $65 \%$, is the most significant in the structure of total revenues [11]. Contrary to the past few years, when net interest revenue had the largest contribution to the growth of banks' profits, in 2017, the largest contribution to the increase in profits came from the non-interest revenue. That is to say, in 2017 there was a slowdown in the annual growth of the net interest revenue of banks, due to the decline in interest revenue from nonfinancial companies. On the other hand, the growth of non-interest revenue does not arise from the introduction of new financial products or services, but is mainly due to the increase in non-operating revenue of a largely unrepeatable character, such as the collected previously written off claims and capital gains from the sale of assets [11]. In the period from 2007 to 2014, net interest revenue was almost continuously increasing the already predominant share in the structure of total revenues. In 2015 and 2016, the share of net interest revenue remained almost unchanged, and in 2017 this share decreased by 2 percentage points. Within the same time period, commission fees reduced their share in the total revenues, and a slightly greater variability is noted in the shares of other regular revenues, which have been increasing in the past three years. Such observations only confirm the application of the traditional business model in the operation of banks the Republic of North Macedonia and even indicates the strengthening of the same. In other words, it is obvious that the banks do not achieve a significant expansion of their operations with some non-traditional activities, which would bring them additional revenue from commissions and consequently, greater diversification of the total revenues. On the other hand, the more pronounced volatility of the shares of other non-interest regular revenues only confirms their predominantly random character.

The aim of this paper is to assess the relative efficiency of commercial banks in the Republic of North Macedonia by using the leading non-parametric frontier methodology - data envelopment analysis (DEA). DEA enables the measurement of the relative efficiency of decisionmaking units (DMUs), that use multiple inputs to produce multiple outputs. When the sample of analysis is small and multiple inputs and outputs are selected, then the efficiency frontier could be constructed by most of the DMUs. To overcome this problem, the DEA technique window analysis could be selected as the most adequate one, which can increase the number of DMUs. In addition, the window analysis allows time dimension in the efficiency analysis to be included. Panel data of eleven years (from 2007 to 2017) is used in this paper, and in order to consider the trend of efficiency of the commercial banks in the observed period, window analysis is chosen as the most appropriate DEA technique. 
Our research has the following two objectives: 1) to identify inputs and outputs that will be used for measuring the relative efficiency of the commercial banks; 2) to solve the DEA window analysis model with software support and to present and interpret the obtained results.

The reminder of this paper is organized as follows. In Section 2 literature review is given. In Section 3 the methodology and sample data are described. In Section 4 the obtained results are presented and discussed while Section 5 concludes the paper.

\section{Literature review}

According to DEA bibliography published in 2008 [8], that covers over 4000 research articles published in the period from 1978 up to 2007, the following areas are identified as the most popular for DEA application: banking, education, healthcare and hospital efficiency [7].

DEA in banking is applied for the following problems [21]: a) analysis of banks operating within one country, b) analysis of bank branches in one bank, c) analysis of banks in two or more countries, d) efficiency of bank mergers and e) banking branch development strategies.

In this paper, the DEA is used to assess the relative efficiency of banks in the Republic of North Macedonia, which means that it is an analysis of banks operating in the country, and special attention is placed on application of the DEA window analysis technique.

Hartman \& Storbeck [14] use window analysis to investigate the development of the lending efficiency of 12 Swedish banks over a period of 9 years. Asmild et al. [2] combine window analysis with Malmquist indexes in a study of the Canadian banking industry. Kisielewska et al. [16] assess the cost efficiency of the 10 largest banks in Poland in a nine-year period (1995-2003) using DEA and they assess productivity change over time using the Malmquist productivity index. In the Polish banking industry six input - oriented models are used, with constant returns to scale (CRS) assumption and they have found that retail-focused banks tend to be more efficient in comparison with corporate focused banks. Savic et al. [23] use the DEA window analysis technique to measure the performance of 28 commercial banks in Serbia from 2005 to 2011. In the Serbian banking industry the intermediation approach along with two models: the profit efficiency model and the operating efficiency model are used. Based on the obtained results, the majority of Serbian banks show an efficiency score which is between $60 \%$ and $70 \%$ regardless of the used model. Repkova [22] has estimated the efficiency of 12 commercial banks in Slovakia in the period from 2003 to 2012 all while using the DEA window analysis approach. The average efficiency of commercial banks in Slovakia estimated using the Charnes-Cooper-Rhodes (CCR) model, ranges from $77 \%$ to $91 \%$, while estimated using the Banker-Charnes-Cooper (BCC) model, ranges from $83 \%$ to $94 \%$. In the Slovak banking sector, the medium-size and small banks are more efficient than the large banks. The average efficiency in the period 2003-2008 increased, while during the period 2010-2011 it decreased, probably as a result of the financial crisis, and these results coincide with those in [1].

In the Republic of North Macedonia, the authors have found the following papers regarding the application of DEA in banks: Micajkova and Poposka [17], Naumovska and Cvetkoska [18], Naumovska and Cvetkoska [19], and Fotova Čiković and Cvetkoska [12] (Table 1). 


\begin{tabular}{|c|c|c|c|}
\hline Authors & Period/Variables & $\begin{array}{l}\text { DEA } \\
\text { model }\end{array}$ & Results \\
\hline $\begin{array}{l}\text { Micajkova } \\
\text { and } \\
\text { Poposka } \\
{[17]}\end{array}$ & $\begin{array}{l}2008-2011 \\
\text { Inputs- total deposits received and la- } \\
\text { bor costs; Outputs - loans to banks } \\
\text { and customers, and investments. }\end{array}$ & $\begin{array}{l}\text { CCR } \\
\text { and BCC } \\
\text { (input- } \\
\text { oriented) }\end{array}$ & $\begin{array}{l}\text { The average efficiency of the Mace- } \\
\text { donian banking sector increased in } \\
\text { the period from } 2008 \text { to } 2010 \text {, while } \\
\text { it decreased in the last year of the } \\
\text { observed period, i.e. in } 2011 \text {. In } \\
\text { this banking sector the highest pure } \\
\text { efficiency scores and the greatest } \\
\text { scale inefficiency were noted in the } \\
\text { group of large banks. }\end{array}$ \\
\hline $\begin{array}{l}\text { Naumovska } \\
\text { and } \\
\text { Cvetkoska } \\
{[18]}\end{array}$ & $\begin{array}{l}2007-2013 \\
\text { Inputs - deposits and operating costs; } \\
\text { Outputs - loans and net interest rev- } \\
\text { enue }\end{array}$ & $\begin{array}{l}\text { CCR } \\
\text { (output- } \\
\text { oriented) }\end{array}$ & $\begin{array}{l}\text { No bank has been efficient in all } \\
\text { of the observed years. The high- } \\
\text { est number of efficient banks (i.e. } 6 \\
\text { banks) has been identified in } 2008 \text {, } \\
\text { whereas the lowest number of effi- } \\
\text { cient banks (i.e. } 3 \text { banks) has been } \\
\text { identified in } 2011 \text { and } 2012 \text {. The av- } \\
\text { erage efficiency of the Macedonian } \\
\text { banking sector has been the high- } \\
\text { est in } 2008(90.35 \%) \text { and the lowest } \\
\text { in } 2012(79.83 \%) \text {. }\end{array}$ \\
\hline $\begin{array}{l}\text { Naumovska } \\
\text { and } \\
\text { Cvetkoska } \\
{[19]}\end{array}$ & $\begin{array}{l}\text { 2007-2013 } \\
\text { Inputs - deposits and operating costs; } \\
\text { Outputs - loans and net interest rev- } \\
\text { enue }\end{array}$ & $\begin{array}{l}\text { BCC } \\
\text { (output- } \\
\text { oriented) }\end{array}$ & $\begin{array}{l}\text { The average efficiency of the Mace- } \\
\text { donian banking sector has been the } \\
\text { highest in } 2008(93.66 \%) \text { and the } \\
\text { lowest in } 2009(86.96 \%) \text {. In } 2013,5 \\
\text { of the banks were identified as rela- } \\
\text { tively inefficient. }\end{array}$ \\
\hline $\begin{array}{l}\text { Fotova } \\
\text { Čiković } \\
\text { and } \\
\text { Cvetkoska } \\
{[12]}\end{array}$ & $\begin{array}{l}\text { 2008-2015 } \\
\text { Inputs - total deposits (deposits from } \\
\text { banks and other clients), interest } \\
\text { costs and operating (non-interest) costs } \\
\text { (costs for salaries, amortization, ad- } \\
\text { ministrative costs and other operating } \\
\text { costs); Outputs- total loans (issued to } \\
\text { banks and other clients) interest rev- } \\
\text { enue and non-interest revenue (fee and } \\
\text { commission revenue and other operat- } \\
\text { ing revenue). }\end{array}$ & $\begin{array}{l}\text { DEA } \\
\text { Window } \\
\text { analysis } \\
\text { model } \\
\text { (output- } \\
\text { oriented) }\end{array}$ & $\begin{array}{l}\text { The average efficiency of the Mace- } \\
\text { donian banking sector in the ob- } \\
\text { served period is } 88.77 \% \text {. There is } \\
\text { no bank that is relatively efficient } \\
\text { in every year in every window. The } \\
\text { results indicate that } 28.57 \% \text { of the } \\
\text { banks have an overall efficiency by } \\
\text { years that is higher than } 95 \% \text {. The } \\
\text { group of large banks has the highest } \\
\text { efficiency in the Macedonian bank- } \\
\text { ing sector. }\end{array}$ \\
\hline
\end{tabular}

Table 1: DEA applications in the Macedonian banking sector

\section{Methodology and data}

There are two approaches to analyzing the efficiency of entities: the parametric approach and the non-parametric approach. In this paper, the focus is on the non-parametric approach, more specifically on DEA. For the parametric approach, see [13].

DEA is a specially designed methodology for measuring the relative efficiency of decisionmaking units, introduced in the literature of the operational research (OR) discipline by Charnes, Cooper, and Rhodes in 1978. Charnes, Cooper, and Rhodes [4] have extended Farrell's idea [9] by linking the calculation of technical efficiency and production frontier, so that the relative technical efficiency of each decision-making unit is calculated as a ratio between the weighted 
output and the weighted input. The weights (multipliers), for both output and input variables must be chosen in a way that calculates the Pareto efficiency measure of each DMU in the observed sample, so that the result of the relative efficiency of each of the DMUs can not be greater than $1[5]$.

It is important for the decision-making units to be homogeneous entities, i.e. they should use the same resources (in DEA known as inputs) to produce the same results (in DEA known as outputs), although they may be in different amounts [25]. The DEA allows the maximum performance measure for each decision-making unit to be calculated against the other decisionmaking units which are part of the observed population, with only one requirement - the decision-making unit must either lie on the efficient frontier or be below it [5].

In this paper the application of DEA is in the banking sector in the Republic of North Macedonia. Commercial banks in North Macedonia, tend to make profit by collecting deposits and approving loans. Their main goal is profit maximization. In that direction, we want to assess the profit efficiency of the commercial banks in North Macedonia by using DEA.

Due to the fact that we have not found a reference in the Republic of North Macedonia where the profit efficiency model is considered and implemented, we realized that such an analysis is important in order to give insights to Macedonian banks of the relative efficiency over time that will help the identified inefficient banks to improve their efficiency. Savic et al. [23] have analyzed profit efficiency from intermediation aspect and we use their model in the selection of the variables. As inputs we use interest and non-interest expenses, while the outputs are interest and non-interest revenues. The observed period is 11 years (2007-2017). Taking into account that we have a panel data and we also want to monitor the trend of the relative efficiency of the commercial banks in the observed period, we are using the DEA window analysis model. The model is output-oriented. Output orientation means that the objective of the model is to maximize the outputs by using the given level of inputs [6]. By using the DEA technique Window analysis, the changes in efficiency of the DMU over time can be observed but only given the assumption that the production possibilities remained the same during the whole period of analysis. When using DEA, the specification of the returns to scale assumption is crucial. The CRS means that the increase in the inputs lead to a proportial increase in the outputs, while the variable returns to scale (VRS) means that the increase in inputs does not lead to a proportional change in the outputs. We have run the window analysis model first by specifying the CRS assumption and than VRS assumption. When we compared the the obtained results with CRS and VRS assumption it was identified a big difference, and in such a case it is better to assume VRS (results are available upon request).

We are using the DEA technique window analysis under VRS assumption, based on the BCC model. The BCC model one of basic DEA models, details can be found in Banker et al. [3]. What follows is the envelopment form of the output-oriented BCC model [6]:

$$
\begin{array}{ll}
\left(B C C-O_{o}\right) & \max _{\eta_{B}, \lambda} \eta_{B}, \\
\text { s.t. } & \\
& X \lambda \leq x_{0} \\
& \eta_{B} y_{0}-Y \lambda \leq 0 \\
& e \lambda=1 \\
& \lambda \geq 0
\end{array}
$$

where $\eta_{B}$ is a scalar. The input data for $D M U_{j}(j=1,2, \ldots, n)$ are $\left(x_{1 j}, x_{2 j}, \ldots, x_{m j}\right)$, and the output data are $\left(y_{1 j}, y_{2 j}, \ldots, y_{s j}\right)$; the data set is given by two matrices $X$ and $Y$, where $X$ is the input matrix and $Y$ is the output matrix, $\lambda$ is a column vector and all its elements are 
non-negative, while $e$ is a row vector and all its elements are equal to 1 [6]. The objective function (1) is always greater or equal than 1 . DMUs with result of 1 will be relative efficient, while those with a result greater than 1 will be relative inefficient. In this paper instead of presenting inefficiency scores we are using the reciprocal values that are efficiency scores of the DMUs and could be better interpreted.

The idea of window analysis is that the same DMU in the period $i$, and in the period $j$ (for $i \neq j$ ) is observed like two different DMUs; $p$ is the length of the window (a number of periods to be observed). First to be observed is the data for the first $p$ period, then the data for the period 1 are omitted and the data for the period $p+1$ are added, and this allows for the next window to be obtained. The data for the first two periods are then omitted and the data for periods $p+1$ and $p+2$ are added, so the next window is obtained, and this is repeated as soon as all of the time periods in the analysis have passed [20]. In window analysis the following symbols and formulas are used: [6]: $n$ - the number of decision-making units, $k$ - the number of periods, $p$ - length of the window $(p \leq k), p=k+1 / 2, w$ - the number of windows $(w=k-p+$ 1 ), the number of decision-making units in each window is calculated according to this formula: $n p$, while the number of "different" decision-making units is calculated through the formula: $n p w$. The obtained results with the window analysis are presented in a table, and the trend can be observed through the rows, while how the result changes or not with the change from one to another window can be noted through the column. A disadvantage of this technique is that the DMUs in the first and the last period are not tested as frequently as others [6].

The sample of analysis consists of 14 commercial banks in the Republic of North Macedonia: Alfa Banka AD Skopje (rebranded into Silk Road Bank AD Skopje in May 2016), Centralna Kooperativna Banka AD Skopje, Eurostandard Banka AD Skopje, Halk Banka AD Skopje, Kapital Banka AD Skopje, Komercijalna Banka AD Skopje, NLB Banka AD Skopje, Ohridska Banka AD Ohrid, ProKredit Banka AD Skopje, Sparkasse Banka AD Skopje, Stopanska Banka AD Bitola, Stopanska Banka AD Skopje, TTK Banka AD Skopje and Uni Banka AD Skopje. The authors have left out the Macedonian Bank for Development Promotion from the analysis because it is not comparable with other banks: it has a specific function in the sector and works on different principles compared to the commercial banks (it is a state-owned bank and is not involved in deposits collection).

We are using data from the revised financial statements for the selected inputs and outputs for each commercial bank in the period from 2007 to 2017. The sample of analysis consists of 14 commercial banks $(n=14)$, eleven years are considered $(k=11)$, the length of the window is 6 years $(p=6)$, and the number of windows is $6(w=k-p+1=11-6+1=6)$. In each window there are 84 banks, and the number of "different" banks is 504. Every window covers 6 years (for example, window 1 covers 6 years: 2007, 2008, 2009, 2010, 2011 and 2012; in the next window (window 2) data for 2007 are omitted and the data for 2013 are added, and so on), as presented in Table 2.

\begin{tabular}{|l|l|l|l|l|l|l|l|l|l|l|l|}
\hline window 1 & 2007 & 2008 & 2009 & 2010 & 2011 & 2012 & & & & & \\
\hline window 2 & & 2008 & 2009 & 2010 & 2011 & 2012 & 2013 & & & & \\
\hline window 3 & & & 2009 & 2010 & 2011 & 2012 & 2013 & 2014 & & & \\
\hline window 4 & & & 2010 & 2011 & 2012 & 2013 & 2014 & 2015 & & \\
\hline window 5 & & & & 2011 & 2012 & 2013 & 2014 & 2015 & 2016 & \\
\hline window 6 & & & & & & 2012 & 2013 & 2014 & 2015 & 2016 & 2017 \\
\hline
\end{tabular}

Table 2: Windows in the DEA window analysis model. Source: Authors

For solving the specified DEA model (Window-O-V) the software DEA-Solver-LV has been used, and details on this software can be found in Cooper et al. [6]. 


\section{Results and discussion}

The obtained results for solving the Window-O-V model are presented in Table 3. According to the results in Table 3 it can be noted that in the post-crisis period, i.e. in the first few years shortly after the global financial crisis, many of the banks note lower efficiency. The lowest average efficiency AE for the whole banking sector was achieved in 2011 (65.25\%), while the highest was achieved in 2007 (84.04\%). From 2012 to 2016 the average efficiency AE for the whole banking sector in Macedonia noted an increase. The increase in efficiency can be interpreted as a consequence of the processes of M\&A in 2012 (when Halk Banka AD Skopje took over Ziraat Banka) and 2014 (when Postenska Banka AD Skopje was acquired by Eurostandard Banka AD Skopje). Stopanska banka AD Bitola had AD Pelisterka as its largest shareholder in 2013, and that was the year that this bank began its modernization and expansion. According to the average efficiency scores, it increased its efficiency after this ownership change, i.e. after the year 2013. As presented in Table 3, there isn't a bank which has noted an efficiency score of 1 in each of the 11 years of the observed period. Furthermore, six banks (Halk Banka AD Skopje, Uni Banka AD Skopje, ProKredit Banka AD Skopje, Eurostandard Banka AD Skopje, Sparkasse Banka AD Skopje, and Ohridska Banka AD Ohrid) have not achieved an efficiency score of 1 in any of the analyzed years.

The overall efficiency (by windows and by years) for the analyzed commercial banks is given in Table 4. The mean efficiency scores in the 6 windows for each bank presents their overall efficiency by windows. The mean of annual efficiency of each bank presents their overall efficiency by years. Based on the presented results (overall efficiency by years) what can be seen in Table 4, is that the most relatively efficient banks are: Stopanska Banka AD Skopje (99.05\%), Komercijalna Banka AD Skopje (96.46\%), and NLB Tutunska Banka AD Skopje $(90.02 \%)$ (these 3 banks belong to the group of large banks (based on the classification of the National Bank of the Republic of North Macedonia according to the total assets of banks for 2017)), while the least efficient bank is one middle-sized bank, i.e. Eurostandard Banka AD Skopje (57.19\%).

\begin{tabular}{|c|c|c|c|c|c|c|c|c|c|c|c|}
\hline & 2007 & 2008 & 2009 & 2010 & 2011 & 2012 & 2013 & 2014 & 2015 & 2016 & 2017 \\
\hline 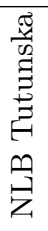 & 0.7797 & $\begin{array}{l}0.7699 \\
0.7541\end{array}$ & $\begin{array}{l}0.7521 \\
0.7521 \\
0.7516\end{array}$ & $\begin{array}{l}0.8531 \\
0.8531 \\
0.8517 \\
0.8473\end{array}$ & $\begin{array}{l}0.9453 \\
0.9439 \\
0.9273 \\
0.9092 \\
0.8874\end{array}$ & $\begin{array}{c}1 \\
0.9965 \\
0.9585 \\
0.9299 \\
0.9161 \\
0.8857\end{array}$ & $\begin{array}{c}1 \\
0.9557 \\
0.9496 \\
0.9359 \\
0.9029\end{array}$ & $\begin{array}{c}1 \\
1 \\
0.9823 \\
0.9378\end{array}$ & $\begin{array}{c}1 \\
0.9778 \\
0.9328\end{array}$ & $\begin{array}{c}1 \\
0.9752\end{array}$ & 1 \\
\hline 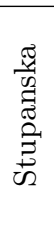 & 1 & $\begin{array}{l}1 \\
1\end{array}$ & $\begin{array}{l}1 \\
1 \\
1\end{array}$ & $\begin{array}{c}0.9982 \\
0.9982 \\
1 \\
1\end{array}$ & $\begin{array}{l}0.9192 \\
0.9192 \\
0.9345 \\
0.9345 \\
0.9620\end{array}$ & $\begin{array}{c}0.9857 \\
0.9857 \\
1 \\
1 \\
1 \\
1\end{array}$ & $\begin{array}{l}0.9636 \\
0.9740 \\
0.9747 \\
0.9900 \\
0.9900\end{array}$ & $\begin{array}{l}1 \\
1 \\
1 \\
1\end{array}$ & $\begin{array}{c}1 \\
0.9827 \\
0.9827\end{array}$ & $\begin{array}{l}1 \\
1\end{array}$ & 1 \\
\hline 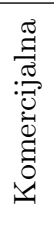 & 1 & $\begin{array}{l}1 \\
1\end{array}$ & $\begin{array}{l}0.8760 \\
0.8551 \\
0.8367\end{array}$ & $\begin{array}{l}0.9017 \\
0.9017 \\
0.9009 \\
0.8994\end{array}$ & $\begin{array}{l}0.9590 \\
0.9590 \\
0.9561 \\
0.9458 \\
0.9333\end{array}$ & $\begin{array}{c}1 \\
1 \\
0.9970 \\
0.9861 \\
0.9731 \\
0.9686\end{array}$ & $\begin{array}{c}1 \\
1 \\
0.9731 \\
0.9558 \\
0.9515\end{array}$ & $\begin{array}{c}1 \\
0.9831 \\
0.9691 \\
0.9393\end{array}$ & $\begin{array}{c}1 \\
1 \\
0.9366\end{array}$ & $\begin{array}{c}1 \\
0.9758\end{array}$ & 1 \\
\hline
\end{tabular}




\begin{tabular}{|c|c|c|c|c|c|c|c|c|c|c|c|}
\hline & 2007 & 2008 & 2009 & 2010 & 2011 & 2012 & 2013 & 2014 & 2015 & 2016 & 2017 \\
\hline 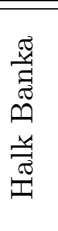 & 0.6114 & $\begin{array}{l}0.5825 \\
0.5751\end{array}$ & $\begin{array}{l}0.5488 \\
0.5742 \\
0.5436\end{array}$ & $\begin{array}{l}0.5252 \\
0.5348 \\
0.4872 \\
0.4355\end{array}$ & $\begin{array}{l}0.6477 \\
0.6570 \\
0.5810 \\
0.5020 \\
0.4562\end{array}$ & $\begin{array}{l}0.7295 \\
0.7045 \\
0.6556 \\
0.5467 \\
0.4926 \\
0.4422\end{array}$ & $\begin{array}{l}0.7814 \\
0.7199 \\
0.5795 \\
0.5181 \\
0.4652\end{array}$ & $\begin{array}{l}0.7288 \\
0.5580 \\
0.5094 \\
0.4630\end{array}$ & $\begin{array}{l}0.6164 \\
0.5507 \\
0.5176\end{array}$ & $\begin{array}{l}0.6390 \\
0.6076\end{array}$ & 0.5828 \\
\hline 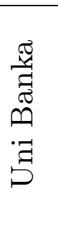 & 0.7228 & $\begin{array}{l}0.6985 \\
0.7089\end{array}$ & $\begin{array}{l}0.5793 \\
0.5536 \\
0.5177\end{array}$ & $\begin{array}{l}0.5586 \\
0.5683 \\
0.4932 \\
0.4027\end{array}$ & $\begin{array}{l}0.6026 \\
0.6336 \\
0.5103 \\
0.4048 \\
0.3654\end{array}$ & $\begin{array}{l}0.6718 \\
0.7349 \\
0.5330 \\
0.4016 \\
0.3781 \\
0.3498\end{array}$ & $\begin{array}{l}0.9843 \\
0.6356 \\
0.5002 \\
0.4318 \\
0.4186\end{array}$ & $\begin{array}{l}0.9468 \\
0.7398 \\
0.6207 \\
0.5510\end{array}$ & $\begin{array}{l}0.7960 \\
0.6697 \\
0.5958\end{array}$ & $\begin{array}{l}0.6336 \\
0.5762\end{array}$ & 0.7676 \\
\hline 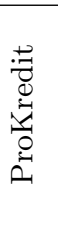 & 0.9833 & $\begin{array}{l}0.9087 \\
0.9330\end{array}$ & $\begin{array}{l}0.8121 \\
0.8313 \\
0.8109\end{array}$ & $\begin{array}{l}0.7590 \\
0.7750 \\
0.7374 \\
0.7554\end{array}$ & $\begin{array}{l}0.7392 \\
0.7800 \\
0.7194 \\
0.6706 \\
0.6922\end{array}$ & $\begin{array}{l}0.7895 \\
0.8096 \\
0.7585 \\
0.6345 \\
0.5440 \\
0.4982\end{array}$ & $\begin{array}{l}0.8320 \\
0.7828 \\
0.6597 \\
0.5563 \\
0.4948\end{array}$ & $\begin{array}{l}0.7979 \\
0.6619 \\
0.5656 \\
0.4951\end{array}$ & $\begin{array}{l}0.7164 \\
0.6361 \\
0.5643\end{array}$ & $\begin{array}{l}0.6878 \\
0.6259\end{array}$ & 0.6440 \\
\hline 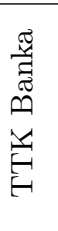 & 0.8842 & $\begin{array}{l}0.6392 \\
0.6673\end{array}$ & $\begin{array}{l}0.5455 \\
0.6023 \\
0.5647\end{array}$ & $\begin{array}{l}0.5797 \\
0.6679 \\
0.6275 \\
0.5812\end{array}$ & $\begin{array}{l}0.6860 \\
0.7691 \\
0.7433 \\
0.6686 \\
0.7261\end{array}$ & $\begin{array}{l}0.7635 \\
0.8535 \\
0.8263 \\
0.7426 \\
0.8151 \\
0.7611\end{array}$ & $\begin{array}{c}1 \\
0.9040 \\
0.7803 \\
0.8307 \\
0.7602\end{array}$ & $\begin{array}{c}1 \\
0.8307 \\
0.8524 \\
0.8154\end{array}$ & $\begin{array}{l}1 \\
1 \\
1\end{array}$ & $\begin{array}{l}1 \\
1\end{array}$ & 0.9374 \\
\hline 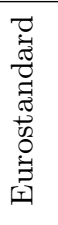 & 0.9320 & $\begin{array}{l}0.7735 \\
0.8154\end{array}$ & $\begin{array}{l}0.7262 \\
0.7902 \\
0.7928\end{array}$ & $\begin{array}{l}0.6129 \\
0.6459 \\
0.6411 \\
0.6028\end{array}$ & $\begin{array}{l}0.4708 \\
0.5249 \\
0.5081 \\
0.5032 \\
0.6589\end{array}$ & $\begin{array}{l}0.4015 \\
0.4239 \\
0.4285 \\
0.4658 \\
0.5784 \\
0.5784\end{array}$ & $\begin{array}{l}0.4439 \\
0.4711 \\
0.5217 \\
0.6670 \\
0.6670\end{array}$ & $\begin{array}{l}0.4204 \\
0.3531 \\
0.3052 \\
0.2753\end{array}$ & $\begin{array}{l}0.4038 \\
0.3729 \\
0.3357\end{array}$ & $\begin{array}{l}0.4189 \\
0.3839\end{array}$ & 0.4918 \\
\hline 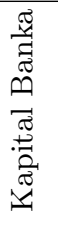 & 1 & $\begin{array}{l}1 \\
1\end{array}$ & $\begin{array}{c}0.7856 \\
0.8567 \\
1\end{array}$ & $\begin{array}{c}0.9396 \\
0.9424 \\
1 \\
1\end{array}$ & $\begin{array}{c}0.3420 \\
0.4084 \\
0.3960 \\
0.3424 \\
1\end{array}$ & $\begin{array}{c}0.4098 \\
0.4463 \\
0.4589 \\
0.4209 \\
0.9725 \\
1\end{array}$ & $\begin{array}{c}0.5682 \\
0.5787 \\
0.5217 \\
1 \\
1\end{array}$ & $\begin{array}{l}0.5729 \\
0.5053 \\
0.7652 \\
0.7457\end{array}$ & $\begin{array}{l}0.5397 \\
0.6631 \\
0.7105\end{array}$ & $\begin{array}{l}0.7797 \\
0.9146\end{array}$ & 0.5996 \\
\hline 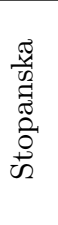 & 0.7524 & $\begin{array}{l}0.7172 \\
0.7564\end{array}$ & $\begin{array}{l}1 \\
1 \\
1\end{array}$ & $\begin{array}{l}0.6842 \\
0.6956 \\
0.6666 \\
0.6411\end{array}$ & $\begin{array}{l}0.6251 \\
0.6352 \\
0.5855 \\
0.5594 \\
0.5194\end{array}$ & $\begin{array}{l}0.6434 \\
0.6616 \\
0.5836 \\
0.5045 \\
0.4850 \\
0.4509\end{array}$ & $\begin{array}{l}0.8055 \\
0.6617 \\
0.5544 \\
0.5815 \\
0.5445\end{array}$ & $\begin{array}{l}0.9715 \\
0.9129 \\
0.8584 \\
0.8213\end{array}$ & $\begin{array}{l}0.6427 \\
0.5919 \\
0.5590\end{array}$ & $\begin{array}{l}0.5833 \\
0.5395\end{array}$ & 0.5327 \\
\hline 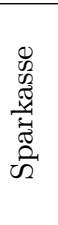 & 0.6795 & $\begin{array}{l}0.6900 \\
0.7648\end{array}$ & $\begin{array}{l}0.6961 \\
0.7037 \\
0.6320\end{array}$ & $\begin{array}{l}0.6441 \\
0.6364 \\
0.5805 \\
0.4903\end{array}$ & $\begin{array}{l}0.6388 \\
0.6087 \\
0.5497 \\
0.4221 \\
0.3856\end{array}$ & $\begin{array}{l}0.7024 \\
0.6708 \\
0.6313 \\
0.5332 \\
0.4605 \\
0.4067\end{array}$ & $\begin{array}{l}0.8987 \\
0.7720 \\
0.6481 \\
0.5944 \\
0.5369\end{array}$ & $\begin{array}{l}0.9166 \\
0.6983 \\
0.6465 \\
0.6118\end{array}$ & $\begin{array}{l}0.9470 \\
0.8193 \\
0.7582\end{array}$ & $\begin{array}{l}0.8727 \\
0.8096\end{array}$ & 0.8660 \\
\hline
\end{tabular}


Assessing the relative efficiency of commercial banks in the Republic of North Macedonia

\begin{tabular}{|c|c|c|c|c|c|c|c|c|c|c|c|}
\hline & 2007 & 2008 & 2009 & 2010 & 2011 & 2012 & 2013 & 2014 & 2015 & 2016 & 2017 \\
\hline \multirow{6}{*}{ 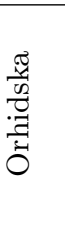 } & 0.7258 & 0.6443 & 0.7143 & 0.7978 & 0.7295 & 0.6506 & & & & & \\
\hline & & 0.6561 & 0.6862 & 0.7656 & 0.6933 & 0.6271 & 0.6630 & & & & \\
\hline & & & 0.6687 & 0.7283 & 0.6723 & 0.6045 & 0.6345 & 0.6471 & & & \\
\hline & & & & 0.6355 & 0.5713 & 0.5021 & 0.5266 & 0.5145 & 0.5710 & & \\
\hline & & & & & 0.4794 & 0.4150 & 0.4421 & 0.4498 & 0.5345 & 0.6490 & \\
\hline & & & & & & 0.3902 & 0.3870 & 0.4010 & 0.4922 & 0.6125 & 0.6657 \\
\hline \multirow{6}{*}{ 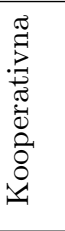 } & 0.6948 & 1 & 1 & 0.6821 & 0.5312 & 0.5048 & & & & & \\
\hline & & 1 & 1 & 0.6954 & 0.5950 & 0.5507 & 0.6158 & & & & \\
\hline & & & 1 & 0.7246 & 0.4729 & 0.5304 & 0.5709 & 0.6918 & & & \\
\hline & & & & 0.9942 & 0.3942 & 0.4581 & 0.5003 & 0.5880 & 0.6015 & & \\
\hline & & & & & 0.4072 & 0.5602 & 0.4778 & 0.5799 & 0.5896 & 0.6229 & \\
\hline & & & & & & 0.5418 & 0.4669 & 0.5579 & 0.5648 & 0.5875 & 0.5306 \\
\hline \multirow{6}{*}{ 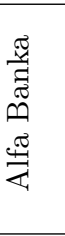 } & 1 & 0.7596 & 0.8254 & 0.6731 & 0.5519 & 0.4693 & & & & & \\
\hline & & 0.7596 & 0.8335 & 0.6776 & 0.5648 & 0.4840 & 0.5887 & & & & \\
\hline & & & 0.8870 & 0.6569 & 0.5501 & 0.4666 & 0.5596 & 0.6097 & & & \\
\hline & & & & 0.6894 & 0.5536 & 0.4428 & 0.5544 & 0.5270 & 0.7821 & & \\
\hline & & & & & 0.6316 & 0.4559 & 0.5130 & 0.5109 & 0.7516 & 0.6721 & \\
\hline & & & & & & 0.4360 & 0.4824 & 0.4790 & 0.7328 & 0.6563 & 0.4739 \\
\hline $\mathrm{AE}$ & 0.8404 & 0.8062 & 0.7835 & 0.7257 & 0.6525 & 0.6599 & 0.7025 & 0.7122 & 0.7248 & 0.7437 & 0.7209 \\
\hline
\end{tabular}

Table 3: Results Window-O-V

\begin{tabular}{|l|cc|}
\hline \multirow{2}{*}{ Bank } & \multicolumn{2}{|c|}{ Overall efficiency } \\
\cline { 2 - 3 } & by windows & by years \\
\hline \hline NLB Tutunska Banka AD Skopje & 0.9115 & 0.9002 \\
Stopanska Banka AD Skopje & 0.9860 & 0.9905 \\
Komercijalna Banka AD Skopje & 0.9593 & 0.9646 \\
Halk Banka AD Skopje & 0.5742 & 0.5773 \\
Uni Banka AD Skopje & 0.5905 & 0.6242 \\
ProKredit Banka AD Skopje & 0.7128 & 0.7370 \\
TTK Banka AD Skopje & 0.7896 & 0.8092 \\
Eurostandard Banka AD Skopje & 0.5391 & 0.5719 \\
Kapital Banka AD Skopje & 0.7274 & 0.7666 \\
Stopanska Banka AD Bitola & 0.6758 & 0.6830 \\
Sparkasse Banka AD Skopje & 0.6645 & 0.7016 \\
Ohridska Banka AD Ohrid & 0.5986 & 0.6201 \\
Centralna Kooperativna Banka AD Skopje & 0.6357 & 0.6659 \\
Alfa Banka AD Skopje & 0.6184 & 0.6615 \\
\hline
\end{tabular}

Table 4: Overall efficiency for commercial banks in North Macedonia

\section{Conclusion}

The financial system in the Republic of North Macedonia is relatively simple and financial markets are still underdeveloped. It is considered to be a bank-based financial system where banks play a crucial role in financing the economic activities and maintaining the financial stability of the system, as well as the stability of the other institutional segments. Banks are the main strings that connect the institutions and participants in the financial system, and they have the highest influence on the total movements in the system. It is safe to assume that the banking sector is the key segment, which can transfer the risks onto the other segments in the 
financial system. Therefore, it is crucial to maintain its stability in order to maintain the total financial stability in the economy.

The DEA technique window analysis is used in this paper to assessed the the profit efficiency of commercial banks in North Macedonia. The sample consists of 14 commercial banks, two inputs (the interest and the non-interest expenses of banks) and two outputs (the interest and the non-interest revenue) are considered as variables, and the observed period is eleven years (2007-2017).

Based on the obtained results, the lowest score of average efficiency of the banking system as a whole was achieved in 2011 (65.25\%), while the highest score of average efficiency was achieved in 2007 (84.04\%). No bank was identified as being relatively efficient in each year in each window, but the most efficient banks belong to the group of large banks.

This is the first study in the Republic of Nort Macedonia in which the profit efficiency of commercial banks is assessed and monitored using the DEA window analysis technique. The main contribution of the conducted research is the fact that the whole banking sector as well as each individual bank have been screened, enabling both generalization and specialization of the results. The results of the presented research are aimed for analysts who are interested in applying DEA for banks' benchmarking as well as for analysts and investors in the North Macedonian commercial banks.

In our future research we plan to explore the determinants of profit efficiency in the context of the Macedonian banks by including contextual variables in the model. The list of the contextual variables will be made by conducting a questionnaire survey with the top management of each bank, while for their selection the multi-criteria decision making method Analytic Hierarchy Process (AHP) will be used.

\section{References}

[1] Anayiotos, G., Toroyan, H., and Vamvakidis, A. (2010). The efficiency of emerging Europe's banking sector before and after the recent economic crisis. Financial Theory and Practice, 34(3), 247-267. https://hrcak.srce.hr/63154

[2] Asmild, M., Paradi, J. C., Aggarwall, V., and Schaffnit, C. (2004). Combining DEA window analysis with the Malmquist Index approach in a study of the Canadian banking industry. Journal of Productivity Analysis, 21, 67-89. doi: 10.1023/B:PROD.0000012453.91326.ec

[3] Banker, R. D., Charnes, A., and Cooper, W. W. (1984). Some models for estimating technical and scale inefficiencies in data envelopment analysis. Management Science, 30(9), 1031-1142. doi: $10.1287 /$ mnsc.30.9.1078

[4] Charnes, A., Cooper, W. W., and Rhodes, E. L. (1978). Measuring efficiency of decision-making units. European Journal of Operational Research, 2(6), 429-444. doi: 10.1016/0377-2217(78)901388

[5] Charnes, A., Cooper, W. W., Lewin, A. Y., and Seiford, L. M. (Eds.). (1994). Data envelopment analysis: Theory, methodology and applications. Boston, MA: Kluwer Academic. doi: 10.1007/97894-011-0637-5

[6] Cooper, W. W., Seiford, L. M., and Tone, K. (2007). Data envelopment analysis: A comprehensive text with models, applications, references and DEA-solver software. New York, NY: Springer Science + Business Media, LLC. doi: 10.1007/978-0-387-45283-8

[7] Cvetkoska, V., and Savic, G. (2017). Efficiency of bank branches: Empirical evidence from a two-phase research approach. Economic Research-Ekonomska istrazivanja, 30(1), 318-333. doi: 10.1080/1331677X.2017.1305775

[8] Emrouznejad, A., Parker, B. R., and Tavares, G. (2008). Evaluation of research in efficiency and productivity: A survey and analysis of the first 30 years of scholarly literature in DEA. Socio Economics Planning Science, 42(3), 151-157. doi: 10.1016/j.seps.2007.07.002

[9] Farrell, M. J. (1957). The Measurement of Productive Efficiency. Journal of Royal Statistical Society, Series A, 120(3), 253-290. doi: 10.2307/2343100 
[10] Financial stability report for the Republic of Macedonia in 2016. (2017) National Bank of the Republic of Macedonia. https://www.nbrm.mk/content/Regulativa/FSR_2016_MKD.pdf

[11] Financial stability report for the Republic of Macedonia in 2017. (2018) National Bank of the Republic of Macedonia. https://www.nbrm.mk/content/FSR_2017.pdf

[12] Fotova Čiković, K., and Cvetkoska, V. (2017). Efficiency of the Macedonian banking sector: A non-parametric approach. CEA Journal of Economics, 12(2), 17-26. http://journal.cea.org. $\mathrm{mk} /$ index $\cdot \mathrm{php} / \mathrm{ceajournal/article/view/115}$

[13] Greene, W. H. (2008). The econometric approach to efficiency analysis. In H. O. Fried, C. A. K. Lovell, and S. S. Schmidt (Eds.) The measurement of productive efficiency and productivity change (pp. 92-250). New York: Oxford University Press. doi: 10.1093/acprof:oso/9780195183528.003.0002

[14] Hartman, T. E., and Storbeck, J. E. (1996). Input congestion in loan operations. International Journal of Production Economics, 46-47, 413-421. doi: 10.1016/S0925-5273(96)00076-X

[15] Khan, F., and Khattak, B. (2016). An empirical investigation of commercial banks' efficiency in Pakistan: A non parametric Data Envelopment approach. Gomal University Journal of Research, 32(1), 21-32. http://www.gujr.com.pk/index.php/GUJR/article/view/137

[16] Kisielewska, M., Guzovska, M., Nellis, J. G., and Zarzecki, D. (2007). Polish banking industry efficiency: a DEA window analysis approach. RP 7/07, Cranfield University School of Management. https://dspace.lib.cranfield.ac.uk/handle/1826/3945

[17] Micajkova, V., and Poposka, K. (2013). Efficiency of Macedonian Banks: A DEA Approach. Research Journal of Finance and Accounting, 4(12), 141-149. https://www . iiste.org/Journals/ index.php/RJFA/article/view/7769/7848

[18] Naumovska, E., and Cvetkoska, V. (2014). Measuring the Efficiency of the Banking Sector in the Republic of Macedonia. Annual Collection of the Faculty of Economics - Skopje, 49, 221-238.

[19] Naumovska, E., and Cvetkoska, V. (2016). Efficiency of the Macedonian Banking Sector. Yugoslav Journal of Operations Research, 26, 317-329. http://elib.mi.sanu.ac.rs/files/journals/ yjor/56/yujorn57p317-329.PDF

[20] Neralić, L. (1995). About one application of data envelopment analysis in agriculture. In T. Hunjak, Lj. Martić, and L. Neralić (Eds.) Proceedings of the 5th Conference on Operational Research (pp. 204-214). Croatian Operational Research Society, Rab, Croatia.

[21] Paradi, J. C., Vela, S., and Yang, Z. (2004). Assessing bank and bank branch performance. In W. W. Cooper, L. M. Seiford, and J. Zhu (Eds. Handbook of Data Envelopment Analysis (pp. 349-400). Boston, MA: Kluwer Academic. doi: 10.1007/1-4020-7798-x_13

[22] Řepková, I. (2014). Efficiency of the Slovak Commercial Banks Applying the DEA Window Analysis. International Journal of Social, Management, Economics and Business Engineering, 8, 12621267. doi: 10.5281/zenodo.1092427

[23] Savić, G., Radosavljević, M., and Ilievski, D. (2012). DEA window analysis approach for measuring the efficiency of Serbian banks based on panel data. Management - Journal for theory and practice of management, 17(65), 5-14. doi: 10.7595/management.fon.2012.0028

[24] Stojanović, A. (2005). Uzroci i posljedice vlasničkog restrukturiranja banaka u zemljama Srednje i Istočne Europe. Novac, Bankarstvo i Financijska tržišta, Adverta Zagreb, 211-212.

[25] Thanassoulis, E. (2001). Introduction to the theory and application of data envelopment analysis: A foundation text with integrated software. Boston, MA: Kluwer Academic. doi: 10.1007/978-14615-1407-7 